\author{
Philippe Montravers \\ Olivier Leroy \\ Christian Eckmann
}

\section{Intra-abdominal candidiasis: it's still a long way to get unquestionable data}

Received: 20 May 2015

Accepted: 20 May 2015

Published online: 19 June 2015

(C) Springer-Verlag Berlin Heidelberg and ESICM 2015

This article refers to the article available at: doi: 10.1007/s00134-015-3866-2.

P. Montravers (

Department of Anaesthesiology and Critical Care Medicine, CHU Bichat Claude Bernard, HUPNVS, APHP,

Paris Diderot Sorbonne Cité University, Paris, France

e-mail: philippe.montravers@bch.aphp.fr

Tel.: +33140256024

O. Leroy

Medical ICU, Chatilliez Hospital, Tourcoing, France

C. Eckmann

Klinikum Peine Academic Hospital, Academic Hospital of Medical University, Hannover, Germany

Intra-abdominal candidiasis (IAC) appears as the second most frequent cause of invasive fungal infection in the intensive-care unit (ICU) [1]. In the AmarCand 1 study, a prospective, multicenter, French observational study, IAC was observed in $34 \%$ of ICU patients with proven invasive candidiasis [1]. Intra-abdominal candidiasis accounts for more than $10 \%$ of all cases of peritonitis and is associated with mortality rates between 25 and $60 \%[2,3]$.

Intra-abdominal candidiasis shares many similarities with candidaemia, including conventional risk factors [4] and high morbidity and mortality rates $[2,3,5]$. While the need for early and adequate antifungal treatment of candidaemia has been clearly demonstrated, no clinical study has ever assessed the need to treat IAC, raising the question of the real pathogenicity of these organisms.
Based on the demonstration that delayed antifungal treatment in candidaemia is a factor of poor prognosis, empirical broad-spectrum antifungal treatment is routinely prescribed in IAC. Interestingly, American and European guidelines do not address this issue while the IDSA guidelines for intra-abdominal infections give only weak therapeutic recommendations [6].

Recently, a consensus of multinational experts proposed enhanced recommendations for the management of IAC [7]. Using these criteria, Bassetti et al., in an article recently published in Intensive Care Medicine, reported a retrospective international cohort of 481 patients treated for IAC [8]. The authors should be congratulated for the largest cohort of IAC ever published and for the interesting data presented here. Their results deserve some comments to emphasize the complexity for organizing studies on this topic.

Despite their attempt to obtain a homogeneous cohort, there is room for improvement in future trials. Their study population gathered together different clinical situations (secondary and tertiary peritonitis, abdominal abscesses, pancreatitis, etc.) in patients with very different underlying diseases and medical history (hospitalized in ICU and surgical wards but also in medical wards, hematology, oncology, etc.) with different levels of severity (with or without septic shock) related to community-acquired, health care-associated and hospital-acquired infections. Overall, a $49.5 \%$ mortality rate was observed in ICU patients compared to $22.8 \%$ in non-ICU patients. Not surprisingly, septic shock and high APACHE II score appeared as independent predictors of mortality, all the more so in patients with these life-threatening conditions who were not all admitted in ICU.

A second important issue in the manuscript of Bassetti et al. is the strong correlation between inadequate source control and increased mortality [8]. These findings confirm what some of the authors have recently published [9]. Interestingly, the issue of source control is a matter of 
concern in many clinical trials. This term comprises a broad range of possible different measures, from the removal of a catheter, to radiological interventions like CT-controlled drainage, and ending in extensive surgical procedures including re-laparotomy or repeated abdominal lavage. Unfortunately, most of the studies dealing with complicated intra-abdominal infections in the infectious disease literature do not describe what exactly is meant by "source control". This point should be considered as at least a weakness. Recently, Solomkin et al. addressed this issue and retrospectively analyzed clinical trials for antibiotics in complicated intra-abdominal infections focusing on the quality of source control [10]. They found incomplete assessment in almost every study. Overall, the authors recommended an interdisciplinary adjudication committee (minimum requirements: surgeon, intensivist and radiologist) for every case suspected of inadequate source control, and provided a checklist of 31 items [10].

One additional point needs to be emphasized in which only limited progress has been made over the last decades. In all the papers addressing the issue of IAC, and the paper from Bassetti does not break the rule, the burden of proof of candida infection cannot be clearly obtained. In many cases, untreated candida species are cleared rapidly from the peritoneal space with no consequences. In some patients, usually described as having IAC, true infection occurs, with intra-abdominal abscesses, persistent growth on repeated surgery, and a risk of blood and tissular dissemination [11]. These patients at increased risk of IAC are mainly those with recurrent intestinal perforations and/or those with a high initial candida growth on semi-quantitative cultures [11]. Consequently, the diagnosis of IAC is based on assumptions, surrogates and indirect evidence.
Close monitoring of these at-risk patients by means of repeated surveillance cultures could be useful. However, the vast majority of these patients are referred from surgical wards in which candida colonization surveillance is rarely performed, transferred from other institutions, or even urgently re-admitted. Fungal biomarkers such as $\beta$-D-glucan might be of interest to identify those patients who really need to be treated $[12,13]$, while procalcitonin assays appear to be fairly disappointing [13]. Unfortunately, these assays are not yet routinely performed and their value in this specific subpopulation is still under investigation.

The retrospective study of Bassetti et al. [8], as well as the prospective AmarCand study [1], demonstrate that the recruitment of large multicenter cohorts is feasible, even in complex surgical cases. Due to the diversity of clinical manifestations of IAC, future investigators should seek for homogenous populations to more closely address the diagnosis and therapeutic issues of these complex cases. The framework of the multinational consensus brings the opportunity for better definitions and enhanced inclusion/ exclusion criteria [7]. Some specific sub-categories of patients at high risk of IAC could be identified in future trials, illustrated in Table 1. Finally, the results of the study from Bassetti et al. get us to the very essence of intraabdominal infections [8]. There is no chance for survival without adequate measures to control the source of the infection. In light of these results, we desperately need not only standardized stewardship protocols for the use of antifungals but also standardized source control reviews in intra-abdominal infections. The embarrassingly high mortality rate in IAM implicates one simple message: a close interaction between intensivists, radiologists and surgeons as "brothers in arms" is of utmost importance to successfully approach this "multi-therapeutic" entity and to change the course of our patients [14].

Table 1 Guide for selection of the study populations and explanations for heterogeneity of published series

\begin{tabular}{|c|c|c|c|c|c|}
\hline $\begin{array}{l}\text { Medical } \\
\text { history }\end{array}$ & Underlying diseases & Acquisition & Clinical situation & Severity & Management \\
\hline $\begin{array}{r}\text { Surgical } \\
\text { wards }\end{array}$ & No underlying disease & $\begin{array}{l}\text { Community- } \\
\text { acquired }\end{array}$ & Primary peritonitis & $\begin{array}{l}\text { No sign of } \\
\text { severity }\end{array}$ & Empirical therapy \\
\hline $\mathrm{ICU}$ & Solid transplant & Hospital-acquired & $\begin{array}{l}\text { Secondary } \\
\text { peritonitis }\end{array}$ & Septic shock & Adequacy of: \\
\hline \multirow[t]{5}{*}{$\begin{array}{r}\text { Medical } \\
\text { wards }\end{array}$} & Cirrhosis & \multirow[t]{5}{*}{$\begin{array}{l}\text { Health-care } \\
\text { associated }\end{array}$} & Tertiary peritonitis & \multirow[t]{5}{*}{$\begin{array}{l}\text { High severity } \\
\text { scores }\end{array}$} & - Antifungal treatment \\
\hline & Steroid therapy & & Pancreatitis & & $\begin{array}{l}\text { - Antibacterial } \\
\text { treatment }\end{array}$ \\
\hline & Neutropenia & & $\begin{array}{l}\text { Biliary tract } \\
\text { infection }\end{array}$ & & - Source control \\
\hline & $\begin{array}{l}\text { Other causes of } \\
\text { immunosuppression }\end{array}$ & & & & \\
\hline & Solid tumor & & & & - Central catheter \\
\hline
\end{tabular}


Conflicts of interest PM has received research grants and/or educational grants and/or speaker's honoraria and/or consultant's honoraria from (in alphabetic order): Astellas, AstraZeneca, Basilea, Cubist, Merck, Sharp and Dohme-Chibret, Pfizer and The Medicines Company. OL has received research grants and/or educational grants and/or speaker's honoraria and/or consultant's honoraria from (in alphabetic order): Abbott, Astellas, AstraZeneca, Merck, Sharp and Dohme-Chibret, Novartis, Sanofi and Pfizer. CE has received research grants and/or educational grants and/or speaker's honoraria and/or consultant's honoraria from (in alphabetic order): Astellas, AstraZeneca, Bayer, Cubist, Merck, Sharp and Dohme-Chibret, and Pfizer.

\section{References}

1. Leroy O, Gangneux JP, Montravers P, Mira JP, Gouin F, Sollet JP, Carlet J, Reynes J, Rosenheim M, Regnier B, Lortholary O (2009) Epidemiology, management, and risk factors for death of invasive Candida infections in critical care: a multicenter, prospective, observational study in France (2005-2006). Crit Care Med 37(5):1612-1618. doi: 10.1097/CCM.0b013e31819efac0

2. Dupont H, Paugam-Burtz C, MullerSerieys C, Fierobe L, Chosidow D, Marmuse JP, Mantz J, Desmonts JM, Desmonts JM (2002) Predictive factors of mortality due to polymicrobial peritonitis with Candida isolation in peritoneal fluid in critically ill patients. Arch Surg 137(12):1341-1346

3. Montravers P, Dupont H, Gauzit R, Veber B, Auboyer C, Blin P, Hennequin C, Martin C (2006) Candida as a risk factor for mortality in peritonitis. Crit Care Med 34(3):646-652

4. Guery BP, Arendrup MC, Auzinger G, Azoulay E, Borges Sa M, Johnson EM, Muller E, Putensen C, Rotstein C, Sganga G, Venditti M, Zaragoza Crespo R, Kullberg BJ (2009) Management of invasive candidiasis and candidemia in adult non-neutropenic intensive care unit patients: part I epidemiology and diagnosis. Intensive Care Med 35(1):55-62. doi: 10.1007/s00134-008-1338-7

5. Montravers P, Mira JP, Gangneux JP, Leroy O, Lortholary O (2011) A multicentre study of antifungal strategies and outcome of Candida spp. peritonitis in intensive-care units. Clin Microbiol Infect 17(7):1061-1067. doi: 10.1111/j.1469-0691.2010.03360.x

6. Solomkin JS, Mazuski JE, Bradley JS, Rodvold KA, Goldstein EJ, Baron EJ, O'Neill PJ, Chow AW, Dellinger EP, Eachempati SR, Gorbach S, Hilfiker M, May AK, Nathens AB, Sawyer RG, Bartlett JG (2010) Diagnosis and management of complicated intraabdominal infection in adults and children: guidelines by the Surgical Infection Society and the Infectious Diseases Society of America. Clin Infect Dis 50(2):133-164. doi: $10.1086 / 649554$
7. Bassetti M, Marchetti M, Chakrabarti A, Colizza S, Garnacho-Montero J, Kett DH, Munoz P, Cristini F, Andoniadou A, Viale P, Rocca GD, Roilides E, Sganga G, Walsh TJ, Tascini C, Tumbarello M, Menichetti F, Righi E, Eckmann C, Viscoli C, Shorr AF, Leroy O, Petrikos G, De Rosa FG (2013) A research agenda on the management of intra-abdominal candidiasis: results from a consensus of multinational experts. Intensive Care Med 39(12):2092-2106. doi: 10.1007/s00134-013-3109-3

8. Bassetti M, Righi E, Ansaldi F, Merelli M, Scarparo C, Antonelli M, GarnachoMontero J, Diaz-Martin A, PalaciosGarcia I, Luzzati R, Rosin C, Lagunes L, Rello J, Almirante B, Scotton PG, Baldin G, Dimopoulos G, Nucci M, Munoz P, Vena A, Bouza E, de Egea V, Colombo AL, Tascini C, Menichetti F, Tagliaferri E, Brugnaro P, Sanguinetti M, Mesini A, Sganga G, Viscoli C, Tumbarello M (2015) A multicenter multinational study of abdominal candidiasis: epidemiology, outcomes and predictors of mortality. Intensive Care Med. doi: 10.1007/s00134-015-3866-2

9. Bassetti M, Righi E, Ansaldi F, Merelli M, Trucchi C, De Pascale G, DiazMartin A, Luzzati R, Rosin C, Lagunes L, Trecarichi EM, Sanguinetti M, Posteraro B, Garnacho-Montero J, Sartor A, Rello J, Rocca GD, Antonelli M, Tumbarello M (2014) A multicenter study of septic shock due to candidemia: outcomes and predictors of mortality. Intensive Care Med 40(6):839-845. doi: 10.1007/s00134-014-3310-z
10. Solomkin JS, Ristagno RL, Das AF, Cone JB, Wilson SE, Rotstein OD, Murphy BS, Severin KS, Bruss JB (2013) Source control review in clinical trials of anti-infective agents in complicated intra-abdominal infections. Clin Infect Dis 56(12):1765-1773. doi: $10.1093 / \mathrm{cid} / \mathrm{cit} 128$

11. Calandra T, Marchetti O (2004) Clinical trials of antifungal prophylaxis among patients undergoing surgery. Clin Infect Dis 39(Suppl 4):S185-S192. doi: $10.1086 / 421955$

12. Tissot F, Lamoth F, Hauser PM, Orasch $C$, Fluckiger U, Siegemund M, Zimmerli S, Calandra T, Bille J, Eggimann P, Marchetti O (2013) betaglucan antigenemia anticipates diagnosis of blood culture-negative intraabdominal candidiasis. Am J Respir Crit Care Med 188(9):1100-1109. doi: 10.1164/rccm.201211-2069OC

13. Leon C, Ruiz-Santana S, Saavedra P, Castro C, Ubeda A, Loza A, MartinMazuelos E, Blanco A, Jerez V, Ballus J, Alvarez-Rocha L, Utande-Vazquez A, Farinas O (2012) Value of beta-Dglucan and Candida albicans germ tube antibody for discriminating between Candida colonization and invasive candidiasis in patients with severe abdominal conditions. Intensive Care Med 38(8):1315-1325. doi: 10.1007/s00134-012-2616-y

14. Eckmann C, Sanchez-Garcia M (2013) Monitoring treatment response in abdominal sepsis with procalcitonin-if only! Crit Care 17(6):1017. doi: $10.1186 / \mathrm{cc} 13154$ 